\title{
Insulin receptor gene polymorphisms in Type 2 (non-insulin-dependent) diabetes mellitus
}

\author{
R.S. Oelbaum, P.M. G. Bouloux, S. R. Li, M. G. Baroni, J.Stocks and D. J. Galton
}

Medical Professorial Unit, St. Bartholomew's Hospital, London, UK

\begin{abstract}
Summary. The insulin receptor has been proposed as a candidate gene for the inherited defect in Type 2 (non-insulindependent) diabetes mellitus and we therefore studied three restriction fragment length polymorphic sites, two revealed with the enzyme Sst1 and one by Rsa1, using two insulin receptor cDNA probes in 131 Caucasian Type 2 diabetic patients and 94 control subjects. The frequency of the six alleles studied did not differ significantly between the two groups. However, one allele, a 6.2 kilobase Rsa 1 fragment $(\mathrm{R}+)$, was found more frequently in those diabetic subjects $(n=48)$
\end{abstract}

with a positive family history of diabetes $(\mathrm{R}+$ frequency $=0.48)$ compared to those diabetic subjects $(n=63)$ with a negative family history $(\mathrm{R}+$ frequency $=0.34, p<0.05)$. These results suggest that this polymorphism may be a linkage marker for the genetic defect in a subgroup of Type 2 diabetic patients with a positive family history.

Key words: Type 2 (non-insulin-dependent) diabetes mellitus, genetics, insulin receptor gene, restriction fragment length polymorphism, population association study.
Type 2 (non-insulin-dependent) diabetes mellitus has strong genetic determinants as shown by high concordance for the disease in monozygotic twins [1]. The disease is unlikely to be monogenic as its inheritance does not follow a Mendelian pattern. While the precise genetic defects have yet to be identified, insulin resistance has been suggested as the primary feature of Type 2 diabetes [2], while others propose a defect of the first phase of insulin secretion [3]. The pathogenesis may involve a two-stage process with chronic insulin resistance due to genetic and/or environmental factors as the primary defect, with compensatory hyperinsulinaemia, and then secondary Beta-cell failure in susceptible islet cells giving rise to the diabetic phenotype.

The cellular mechanisms underlying insulin resistance have received intensive study. Attention has focussed on the possible role of insulin receptor defects in determining insulin resistance. This transmembrane glycoprotein consists of two $\alpha$-subunits, which contain the insulin binding domain, and two $\beta$-subunits which possess tyrosine kinase and autophosphorylation activity [4]. Mutations of the insulin receptor gene have been reported in rare disorders which are characterised by extreme insulin resistance, for example leprechaunism ( Lys $_{460}$ to Glu in one allele and $\mathrm{Gln}_{671}$ to a stop codon in the other) [5], and Type A syndrome (insulin resistance, acanthosis nigricans and virilisation) [6]. Insulin receptors isolated from erythrocytes
[7], adipocytes [8] and hepatocytes [9] of Type 2 diabetic patients all show reduced insulin-stimulated tyrosine kinase activity, reversible by insulin therapy, despite normal insulin binding. This post-binding defect of receptor kinase activity appears to be specific for Type 2 diabetes and is not seen in obese non-diabetic subjects who are insulin resistant [10].

The insulin receptor gene is located on chromosome 19 at 19p13.3-13.2 [11] and is composed of 22 exons and 21 introns spanning a region of greater than 120 kilobase $(\mathrm{kb})$ pairs [12]. Only $10-15 \%$ of the insulin receptor genomic sequence is known but the availability of a cloned human insulin receptor cDNA probe [4] and further characterisation of restriction fragment length polymorphisms (RFLP) around this locus [13] make it feasible to study whether inherited structural defects of the insulin receptor are involved in the aetiology of Type 2 diabetes. If a diabetogenic locus were present within or close to the insulin receptor gene, it may be in linkage disequilibrium with an RFLP marker at this site and several population association studies have suggested that variation at this locus may predispose subjects to Type 2 diabetes [14-18]. In the present study we have examined three polymorphic sites at the insulin receptor locus to see if differences in genotype variants occur between British non-insulin-dependent diabetic and control subjects. 


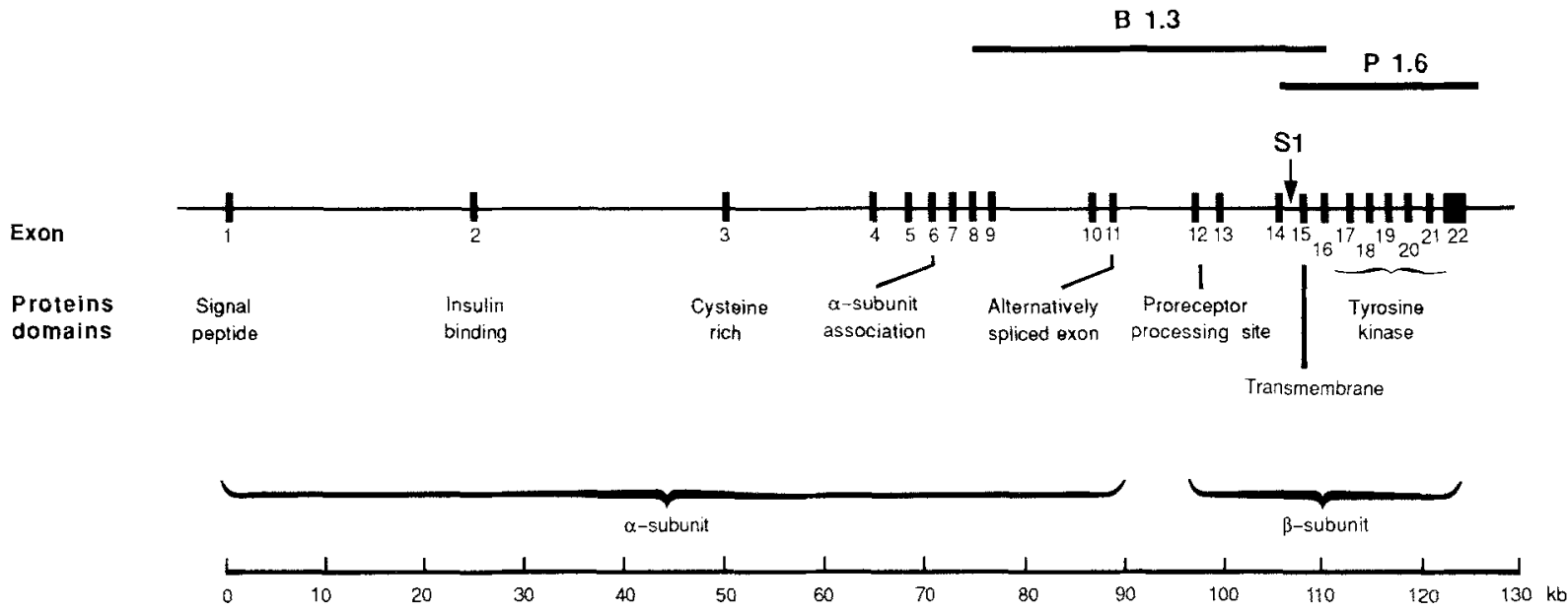

Fig.1. Map of the intron/exon structure of the human insulin receptor gene. Relative locations and sizes of the 22 exons (solid bars) and 21 introns are indicated. Protein domains encoded by each exon or group of exons are below gene map. The regions covered by the cDNA probes B1.3 and P1.6 are shown. The S1 Sst1 polymorphic site described in the text is located in intron 14 as shown [22]. The S2 Sst1 polymorphic site is probably within one of the introns 17 to 21 . The Rsa1 polymorphic locus has been located to within introns 9 to 11 . $\mathrm{kb}=$ kilobase. Modified from reference [12]

\section{Subjects, materials and methods}

\section{Subjects}

131 unrelated Caucasian Type 2 diabetic patients ( 73 male) were recruited from the diabetic clinics at St. Bartholomew's Hospital and Moorefields Eye Hospital. All patients met accepted criteria for Type 2 diabetes [19], and gave their parental origins as SouthEast England. Their mean $( \pm \mathrm{SD})$ age was $65.5( \pm 8.6)$ years and mean $( \pm S D)$ body mass index $(\mathrm{BMI})$ was $27.0( \pm 5.0) \mathrm{kg} / \mathrm{m}^{2}$. The mean age at diagnosis was $55.9( \pm 9.6)$ years and five patients were receiving insulin but had not begun their therapy until at least 5 years after diagnosis. Fifty-two (42\%) of the diabetic subjects gave a positive family history of Type 2 diabetes in at least either one first degree relative or two related second degree relatives. Ninety-four male Caucasian control subjects, with a mean $( \pm \mathrm{SD})$ age of $55.4( \pm 7.2)$ years and mean $( \pm \mathrm{SD})$ BMI of $25.6( \pm 2.6) \mathrm{kg} / \mathrm{m}^{2}$, were recruited from a health screening clinic on the basis of a negative personal and family history of diabetes, and a fasting blood glucose of less than $6 \mathrm{mmol} / \mathrm{l}$. Seventy-three $(61 \%)$ of the diabetic subjects and $52(55 \%)$ of control subjects had a BMI greater than $25 \mathrm{~kg} / \mathrm{m}^{2}$. All subjects gave informed consent to the studies which were approved by the hospital ethical committee.

\section{DNA analysis}

DNA was extracted from $10 \mathrm{ml}$ whole blood as previously described [20]. Digestion of $8 \mu \mathrm{g}$ DNA was carried out with $30 \mathrm{U}$ of Sst1 or Rsa1 restriction endonuclease (BRL, Cambridge, UK) according to the manufacturer's instructions. Some samples were not available for digestion with Rsa1. The resulting fragments were separated by electrophoresis in $0.85 \%$ agarose gels, denatured and blotted onto nylon membranes (Hybond-N, Amersham International, Amersham, UK) by the method of Southern. HindIII digests of lambda DNA were used as size markers. Blots were hybridised with ${ }^{32} \mathrm{P}$-labelled insulin receptor probe for $48 \mathrm{~h}$ at $42^{\circ} \mathrm{C}$ in $50 \%$ formamide and then washed to a final stringency of $0.2 \times \mathrm{SSC} / 0.1 \%$ SDS at $62^{\circ} \mathrm{C}$. Fragments were visualised by autoradiography at $-70^{\circ} \mathrm{C}$ using Hyperfilm-MP (Amersham International).

\section{Construction of probes}

Probes were prepared from a $4.3 \mathrm{~kb}$ cDNA human insulin receptor probe (kindly donated by Dr. A. Ullich, Genentech, San Francisco, Calif., USA) extending from base pair 1013 to the $3^{\prime}$ end, which was cloned in pUC 12. This probe was digested with Pst 1 to yield a $1.6 \mathrm{~kb}$ probe (P1.6) covering base pairs 2744-4343 of the cDNA covering exons 15 to 22 containing most of the $\beta$-subunit including the tyrosine kinase domain, and with Bgl1 to give a $1.3 \mathrm{~kb}$ probe (B1.3) extending from base pairs 1601-2963 of the cDNA covering exons 8 to 16 [13] (Fig. 1). These probes were labelled with ${ }^{32} \mathrm{P}$ by random priming [21].

\section{Statistical analysis}

Differences in genotypic and allelic frequencies between groups were assessed using the $\chi^{2}$ test.

Table 1. Genotype numbers (and frequencies) at Sst1 $\mathrm{S} 1$ and $\mathrm{S} 2$ and Rsa 1 polymorphic sites at the insulin receptor locus in Caucasian Type 2 (non-insulin-dependent) diabetic subjects and control subjects

\begin{tabular}{lcc}
\hline Genotype & $\begin{array}{l}\text { Type 2 diabetic } \\
\text { subjects }\end{array}$ & Control subjects \\
\hline $\mathrm{S} 1+\mathrm{S} 1+$ & $104(79 \%)$ & $73(78 \%)$ \\
$\mathrm{S} 1+\mathrm{S} 1-$ & $26(20 \%)$ & $19(20 \%)$ \\
$\mathrm{S} 1-\mathrm{S} 1-$ & $2(2 \%)$ \\
$\mathrm{S} 2+\mathrm{S} 2+$ & $1(1 \%)$ & $3(3 \%)$ \\
$\mathrm{S} 2+\mathrm{S} 2-$ & $0(0 \%)$ & $17(18 \%)$ \\
$\mathrm{S} 2-\mathrm{S} 2-$ & $24(18 \%)$ & $73(78 \%)$ \\
$\mathrm{R}+\mathrm{R}+$ & $107(82 \%)$ & $7(13 \%)$ \\
$\mathrm{R}+\mathrm{R}-$ & $19(17 \%)$ & $32(60 \%)$ \\
$\mathrm{R}-\mathrm{R}-$ & $51(46 \%)$ & $14(26 \%)$ \\
\hline
\end{tabular}

$\mathrm{S} 1+$ and $\mathrm{S} 1$ - represent 5.3 kilobase $(\mathrm{kb})$ and $5.8 \mathrm{~kb}$ fragments, respectively, $\mathrm{S} 2$ - and $\mathrm{S} 2$ - represent $7.0 / 2.4 \mathrm{~kb}$ or $9.4 \mathrm{~kb}$ fragments, respectively and $\mathrm{R}+$ and $\mathrm{R}$ - represent $6.2 \mathrm{~kb}$ and $6.8 \mathrm{~kb}$ fragments, respectively. No significant differences were found in genotype frequencies between the diabetic group and control population 
A

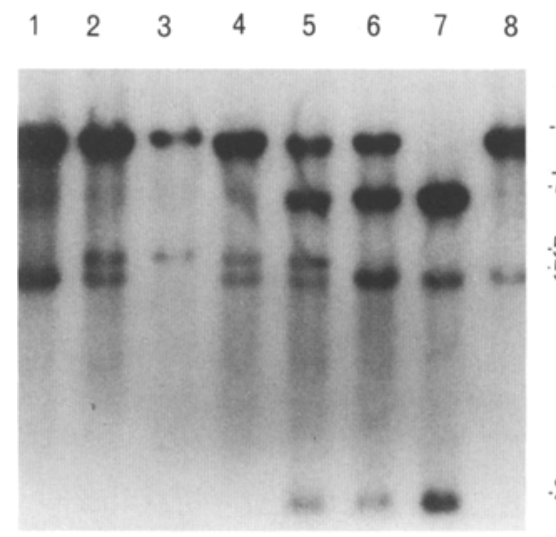

B

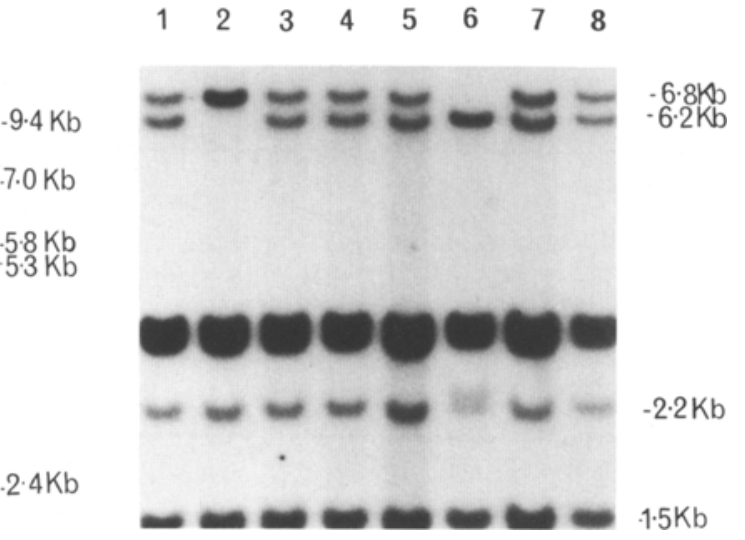

Fig. 2A, B. DNA from unrelated individuals digested with Sst1 (A) or Rsa1 (B), separated on $0.85 \%$ agarose gels, transferred to nylon filters and hybridised with probe P1.6 (A) or B1.3 (B). Fragment sizes are shown in kilobases (kb). (A) For polymorphism S1, individuals 2, 4 and 5 are heterozygous and individual 3 is homozygous for the $S 1-(5.8 \mathrm{~kb})$ allele. All other individuals are homozygous for the $\mathrm{S} 1+(5.3 \mathrm{~kb})$ allele. At the $\mathrm{S} 2$ restriction fragment length polymorphism, individual 7 is homozygous for the $\mathrm{S} 2+(7.0 \mathrm{~kb}$ and $2.4 \mathrm{~kb}$ ) allele, individuals 5 and 6 are heterozygous, and all others are homozygous for the $\mathrm{S} 2-(9.4 \mathrm{~kb})$ allele. (B) For the Rsa1 polymorphism individual 2 is homozygous for the $R-(6.8 \mathrm{~kb})$ allele, individual 6 is homozygous for the $R+(6.2 \mathrm{~kb})$ allele and all others are heterozygous

\section{Results}

Two distinct RFLPs were identified in Sst1 digests following hybridisation with the probe P1.6, being designated the S1 and S2 loci (Fig. 2). The S1 polymorphism results in fragments of $5.3 \mathrm{~kb}$ or $5.8 \mathrm{~kb}$, the alleles being nominated as $\mathrm{S} 1+$ and $\mathrm{S} 1$-, respectively in accordance with convention [13,22] (Fig.2). BamH1, Taq1, Xba1, Pvu11 and Xmn1 all detected di-allelic polymorphisms with bands $0.5 \mathrm{~kb}$ apart using the probe P1.6, and individual genotypes at these loci corresponded exactly with those of the S1 polymorphism, suggesting that the S1 locus represents a 500 base-pair insertion-deletion polymorphism, as suggested previously and which has been localised to the 14th intron (Fig. 1) [22]. The S2 polymorphic locus is characterised by the presence of a $9.4 \mathrm{~kb}$ $(\mathrm{S} 2+)$ fragment or of 7.0 and $2.4 \mathrm{~kb}(\mathrm{~S} 2-)$ fragments (Fig. 2). This polymorphism appears to be caused by the presence $(\mathrm{S} 2+)$ or absence $(\mathrm{S} 2-)$ of an Sst1 site $2.4 \mathrm{~kb}$ from one end of the $9.4 \mathrm{~kb}$ fragment. The probe B1.3 also detected the S1 polymorphism but not the S2 polymorphism. The S1 and S2 RFLPs appear to correspond with those described previously [13, 14,16,23]. A single RFLP was detected with Rsa1 using the probe B1.3, which was characterised by bands of $6.8 \mathrm{~kb}$ or $6.2 \mathrm{~kb}$, designated $\mathrm{R}-$ and $\mathrm{R}+$, respectively according to convention [13] (Fig.2).

A summary of the genotype frequencies at the S1, S2 and Rsa RFLP sites in the diabetic and control subject groups is shown in Table 1 . The genotype distribution in the control subject group at all three polymorphic loci conformed to Hardy-Weinberg proportions. Within the diabetic subject group, there were no significant differences with regard to genotype frequency at all three RFLP sites studied between males and females. There were no overall significant differences in the frequency of any genotype or allele between the diabetic and control subjects at any of the three RFLP sites examined.

As any genetic marker for Type 2 diabetes is likely to be more prevalent in those subjects who have a strong family history of diabetes, we divided the diabetic subject group into those who gave a good positive family history and those who had no family history of diabetes. There was no difference in the allele frequencies at the two polymorphic Sst1 sites between the two diabetic groups but in those diabetic subjects with a positive family history the $\mathrm{R}+(6.2 \mathrm{~kb})$ allele was significantly more common than in those with a negative family history $\left(\chi^{2}=4.31\right.$, $\mathrm{df}=1, p<0.05$ ) (Table 2). We also examined whether any allele was associated with obesity because the genetic predisposition to Type 2 diabetes may express itself more clearly in a subgroup of obese subjects. The frequency of the six alleles within the subgroups of overweight $\left(\mathrm{BMI}>25 \mathrm{~kg} / \mathrm{m}^{2}\right)$ and lean diabetic patients and overweight and lean control subjects is also shown in Table 2. There were no significant differences in allele frequencies at any of the three polymorphic sites when comparing these subgroups in both diabetic and control groups.

Haplotypes were determined from analysis of individuals who were homozygous for at least one RFLP to determine if a particular combination of RFLPs, rather than single alleles, associated with the diabetic phenotype. There was no significant association of any haplotype with the diabetic phenotype. The observed haplotype frequencies for each pair of RFLPs was not significantly different by $\chi^{2}$ analysis from that expected from the respective allele frequencies at each RFLP site, thus making strong linkage disequilibrium between alleles unlikely (data not shown).

\section{Discussion}

Our results show a increased frequency of the $R+$ $(6.2 \mathrm{~kb})$ allele in those Type 2 diabetic subjects with a positive family history of Type 2 diabetes compared to those without. It is probable that any linkage marker for Type 2 
Table 2. Allele frequencies at S1, S2 and Rsa polymorphic sites at the insulin receptor locus in Caucasian subgroups of Type 2 (non-insulindependent) diabetic subjects and control subjects

\begin{tabular}{|c|c|c|c|c|c|c|c|c|}
\hline \multirow[b]{3}{*}{ Subjects } & \multicolumn{8}{|c|}{ Allele frequency } \\
\hline & \multicolumn{5}{|l|}{ Sst1 } & \multicolumn{3}{|l|}{ Rsa1 } \\
\hline & $n$ & $\mathrm{~S} 1+$ & S1 - & $\mathrm{S} 2+$ & $\overline{\mathrm{S} 2-}$ & $\bar{n}$ & $\mathrm{R}+$ & $\mathrm{R}-$ \\
\hline All diabetic subjects & 262 & 0.89 & 0.11 & 0.09 & 0.91 & 222 & 0.40 & 0.60 \\
\hline Lean diabetic subjects & 92 & 0.89 & 0.11 & 0.12 & 0.88 & 80 & 0.36 & 0.64 \\
\hline Obese diabetic subjects & 146 & 0.88 & 0.12 & 0.07 & 0.93 & 126 & 0.41 & 0.59 \\
\hline + ve FH & 104 & 0.88 & 0.12 & 0.09 & 0.91 & 96 & $0.48^{a}$ & 0.52 \\
\hline - ve FH & 142 & 0.91 & 0.09 & 0.10 & 0.90 & 126 & $0.34^{*}$ & 0.66 \\
\hline All control subjects & 188 & 0.88 & 0.12 & 0.12 & 0.88 & 106 & 0.43 & 0.57 \\
\hline Lean control subjects & 84 & 0.88 & 0.12 & 0.13 & 0.87 & 48 & 0.42 & 0.58 \\
\hline Obese control subjects & 104 & 0.88 & 0.12 & 0.12 & 0.88 & 58 & 0.45 & 0.55 \\
\hline
\end{tabular}

$\mathrm{S} 1+$ and $\mathrm{S} 1$ - represent 5.3 kilobases $(\mathrm{kb})$ and $5.8 \mathrm{~kb}$ alleles, respectively, $\mathrm{S} 2+$ and $\mathrm{S} 2 \sim$ represent $7.0 / 2.4 \mathrm{~kb}$ or $9.4 \mathrm{~kb}$ alleles, respectively and $\mathrm{R}+$ and $\mathrm{R}-$ represent $6.2 \mathrm{~kb}$ and $6.8 \mathrm{~kb}$ alleles, respectively. + ve FH and - ve FH represent diabetic subjects with and without family history of diabetes, respectively. Lean and obese refer to $\mathrm{BMI}<25 \mathrm{~kg} / \mathrm{m}^{2}$ and $>25 \mathrm{~kg} / \mathrm{m}^{2}$ respectively. $n=$ number of chromosomes studied.

a $\mathrm{R}+$ allele frequency diabetic subjects with positive family history vs diabetic subjects with negative family history, $\chi^{2}=4.31$, $\mathrm{df}=1$, $p<0.05$; all other differences $p>0.05$ diabetes would be more likely to be found in a subgroup with a positive family history. Population association studies between control subjects who give no family history and diabetic subjects with a positive family history may be more likely to yield results for an aetiological locus.

The results from our study are at variance with two previous studies that reported an association of the S1 $(5.8 \mathrm{~kb})$ allele with Type 2 diabetes in Caucasian populations. The differing conclusions from the two previous studies and this study is due to a difference in the S1 - allele frequency between the control populations, being 0.05 and 0.06 in McClain's and Trembath's studies whereas we found it to be 0.12 . As there appears to be no differences between the control populations with regard to average age and BMI, a possible explanation for this allele frequency difference is heterogeneity between our English Caucasian population and a more genetically diverse North American Caucasian population. Other published frequencies of the S1 - allele in Caucasian control population report values close to ours $[13,23,24]$.

Studies in other racial groups have produced conflicting results in looking for association between RFLPs at the insulin receptor locus and Type 2 diabetes. In a preliminary report [15], McGill et al. reported a weak association of the $\mathrm{S} 1+(5.3 \mathrm{~kb})$ allele with diabetes in an American Black population. In a study of six candidate genes in an American Chinese population [17], a haplotype $\mathrm{X} 2 \mathrm{R} 2 \mathrm{~K} 2$ of the insulin receptor was found significantly less frequently in the diabetic subject group than in the control population, suggesting that in that population some variation at the insulin receptor may contribute to protection from the development of the diabetic phenotype. A recent report from a study of Mexican Americans has also shown a slightly increased "odds ratio" for Type 2 diabetes in subjects homozygous for a $3.4 \mathrm{~kb}$ allele detected with the enzyme Rsa1 [18]. This $3.4 \mathrm{~kb}$ Rsa1 fragment has only been observed in Pima Indians [13] and Mexican Americans [18] and was not found in any of our
164 subjects genotyped at this locus. However, in a study of Punjabi Sikhs [24] no association was found between diabetes and two RFLP markers detected with the enzymes BgIII and BamH1, the latter RFLP corresponding to the S1 RFLP in the present study. We have previously found no association between the two Sst1 insulin receptor RFLPs and Type 2 diabetes in a Japanese population [25]. Studies of Caucasian [26] and Black American [27] diabetic pedigrees found linkage between the insulin receptor and diabetes to be unlikely.

Clear racial differences in insulin receptor allele frequencies exist $[13,24,25]$ and an association of one allele of an RFLP with Type 2 diabetes in one population but not in another may simply reflect differing evolutionary histories of the RFLP between the two populations, and still provide a useful linkage marker. Similarly, because non-insulin-dependent diabetes is probably a heterogeneous disorder, linkage markers might only be identified in a subgroup of Type 2 diabetic subjects.

Acknowledgements. We wish to thank Dr. C. Ritchie, BUPA Medical Centre, London for control subjects. We also thank the Medical Research Council, UK, (RSO), the British Diabetic Association (SRL) and the Accademia Nazionale dei Lincei/Royal Society (MGB) for financial support.

\section{References}

1. Barnett AH, Eff C, Leslie RD, Pyke DA (1981) Diabetes in identical twins: a study of 200 pairs. Diabetologia 20: 87-93

2. Olefsky JM, Ciaraldi TP, Kolterman OG (1985) Mechanism of insulin resistance in non-insulin-dependent (type II) diabetes. Am J Med 79: 12-22

3. O'Rahilly SP, Nugent Z, Rudenski AS, Hosker JP, Burnett MA, Darling P, Turner RC (1986) Beta-cell dysfunction rather than insulin insensitivity is the primary defect in familial type 2 diabetes. Lancet I: 360-363

4. Ullrich A, Bell JR, Chen EY et al. (1985) Human insulin teceptor and its relationship to the tyrosine kinase family of oncogenes. Nature 313: 756-761 
5. Kadowaki T, Bevins CL, Cama A et al. (1988) Two mutant alleles of the insulin receptor gene in a patient with extreme insulin resistance. Science 240: 787-790

6. Moller DE, Flier JS (1988) Detection of an alteration in the insulin receptor gene in a patient with insulin resistance, acanthosis nigricans and the polycystic ovary syndrome (type A insulin resistance). N Engl J Med 319: 1526-1529

7. Comi RJ, Grunberger G, Gorden P (1987) Relationship of insulin binding and insulin-stimulated tyrosine kinase activity is altered in type II diabetes. J Clin Invest 79: 453-462

8. Freidenberg GR, Henry RR, Klein HH, Reichart DR, Olefsky JM (1987) Decreased kinase activity of insulin receptors from adipocytes of non-insulin-dependent diabetic subjects. J Clin Invest $79: 240-250$

9. Caro JF, Ittoop O, Pories WJ et al. (1986) Studies on the mechanism of insulin resistance in the liver from humans with non-insulin-dependent diabetes. J Clin Invest 78: 249-258

10. Mandarino L, Campbell P, Gerich J (1984) Abnormal coupling of insulin receptor binding in non-insulin-dependent diabetes. Am J Physiol 247: E688-E692

11. Yang-Feng TL, Franke U, Ullrich A (1985) Gene for human insulin receptor: localization to a site on chromosome 19 involved in pre-B-cell leukemia. Science 228: 728-731

12. Seino S, Seino M, Bell GI (1990) Human insulin receptor gene: partial sequence and amplification of exons by polymerase chain reaction. Diabetes 39:129-133

13. Elbein SC, Corsetti L, Ulirich A, Permutt MA (1986) Multiple restriction fragment length polymorphisms at the insulin receptor locus: a highly informative marker for linkage analysis. Proc Natl Acad Sci USA 83: 5223-5227

14. McClain DA, Henry RR, Ullrich A, Olefsky JM (1988) Restriction fragment length polymorphism in insulin-receptor gene and insulin resistance in NIDDM. Diabetes 37: 1071-1075

15. McGill J, Corsetti L, Elbein SC (1987) Restriction fragment length polymorphism at the insulin receptor in a population of diabetic and non-diabetic Blacks. Diabetes 36 [Suppl 1]: 21A (Abstract)

16. Galton DJ, Trembath RC (1988) Genetic variants of the insulin receptor in type 2 (non-insulin-dependent) diabetes mellitus. Biomed Biochim Acta 47:323-327

17. Xiang K-S, Cox NJ, Sanz N, Huang P, Karam JH, Bell GI (1989) Insulin-receptor and apoprotein genes contribute to development of NIDDM in Chinese Americans. Diabetes 37: 17-23

18. Raboudi SH, Mitchell BD, Stern MP, Eifler CW, Haffner FM, Hazuda HP, Frazier ML (1989) Type II diabetes mellitus and polymorphisms of insulin-receptor gene in Mexican Americans. Diabetes 38: 975-980

19. World Health Organisation Expert Committee on Diabetes Mellitus Second Report (1980) WHO Technical Report Series 646

20. Ferns GAA, Ritchie C, Stocks J, Galton DJ (1985) Genetic polymorphisms of apoprotein C-III and insulin in survivors of myocardial infarction. Lancet II: 300-303

21. Feinberg AP, Vogelstein B (1983) A technique for radio-labelling DNA restriction endonuclease fragments to high specific activity. Analyt Biochem 132: 6-13

22. Elbein SC (1989) Molecular and clinical characterization of an insertional polymorphism of the insulin-receptor gene. Diabetes 38: 737-743

23. Morgan R, Bishop A, Peters JR, Owens DR, Rees A (1989) Two DNA sequence variants at the insulin receptor gene locus revealed by the restriction endonuclease Sst 1 . Diabetic Med 6 [Suppl 1]: A21 (Abstract)

24. Hitman GA, Karir PK, Mohan V, Rao PV, Kohner EM, Levy JC, Mather H (1987) A genetic analysis of type-2 (non-insulin-dependent) diabetes mellitus in Punjabi Sikhs and British Caucasoid patients. Diabetic Med 4: 526-530

25. Li SR, Oelbaum RS, Stocks J, Galton DJ (1988) DNA polymorphisms of the insulin receptor gene in Japanese subjects with non-insulin dependent diabetes mellitus. Hum Hered 38: 273276

26. O'Rahilly S, Trembath RC, Patel P, Galton DJ, Turner RC, Wainscoat JS (1988) Linkage analysis of the human insulin receptor gene in Type 2 (non-insulin-dependent) diabetic families and a family with maturity onset diabetes of the young. Diabetologia 31: 792-797

27. Cox NJ, Epstein PA, Speilman RS (1989) Linkage studies on NIDDM and the insulin and insulin-receptor genes. Diabetes 38: $653-658$

Received: 25 July 1990

and in revised form: 23 November 1990

Prof. D.J.Galton

Medical Professorial Unit

St. Bartholomew's Hospital

London EC1A

UK 